\title{
ANALISIS HARGA POKOK PENJUALAN PADA LABA DI APOTIK KIMIA FARMA No. 66 LUWUK
}

\author{
Siswadi Sululing dan Doddy Asharudin \\ Fakultas Ekonomi Universitas Muhammadiyah Luwuk \\ email:siswadi.sululing@yahoo.com
}

\begin{abstract}
This study entitled " Analysis of Cost of Goods Sold In Profit In Kimia Farma Pharmacy 66 Luwuk, with the formulation of the problem is : " Is the Price Determination of Sales At Kimia Farma No. 66 Luwuk Has Earned Income Optimal ? "This study aims to determine the Price Determination of Sales and Profits What is optimal at Kimia Farma Pharmacy 66 Luwuk using Descriptive Analysis . The results showed that the calculation of cost of goods sold from 2013 through 2014 can be seen Profits not yet optimal because the sales targets set each year has not been reached. Profit decline that occurs due to declining prescription sales of credit and operational costs which did not experience significant differences .
\end{abstract}

Keywords: Cost of Sales , Earnings

\begin{abstract}
Abstrak: Penelitian ini dengan judul "Analisis Harga Pokok Penjualan Pada Laba Di Kimia Farma Apotek No.66 Luwuk, dengan rumusan masalahnya adalah: "Apakah Penentuan Harga Pokok Penjualan Pada Apotek Kimia Farma No. 66 Luwuk Telah Memperoleh Laba Optimal ?" Penelitian ini bertujuan untuk mengetahui Penentuan Harga Pokok Penjualan dan Apakah Laba yang diperoleh sudah optimal di Kimia Farma Apotek No.66 Luwuk dengan menggunakan metode Analisis Deskriptif. Hasil penelitian ini menunjukkan bahwa perhitungan Harga Pokok Penjualan dari tahun 2013 sampai dengan 2014 dapat diketahui Laba yang diperoleh belumlah optimal karena target penjualan yang ditetapkan setiap tahunnya belum tercapai. Penurunan laba yang terjadi disebabkan menurunnya penjualan resep kredit serta biaya operasional yang tidak mengalami perbedaan yang cukup berarti.
\end{abstract}

Kata kunci: Harga Pokok Penjualan, Laba

\section{PENDAHULUAN}

Perusahaan merupakan organisasi yang mempunyai berbagai tujuan baik jangka panjang maupun jangka pendek. Salah satu tujuan yang penting untuk dicapai adalah pencapaian laba optimum. Pencapaian laba dirasa penting karena berkaitan dengan berbagai konsep akuntansi antara lain kesinambungan perusahaan (going concern) dan perluasan perusahaan, serta mengembangkan usahanya ketingkat yang lebih tinggi atau ketingkat yang lebih baik. Untuk menjamin agar usaha perusahaan mampu menghasilkan laba, maka manajemen perusahaan harus merencanakan dan mengendalikan dengan baik dua faktor penentu laba yaitu pendapatan dan biaya.

Penetapan harga jual adalah salah satu yang berperan besar dalam menentukan keberhasilan bisnis, terutama perusahaan yang bergerak dibidang penjualan barang dan produk. Perusahaan dalam melakukan penentuan dapat dilakukan dengan berbagai cara , salah satu yang paling banyak dipakai adalah dengan menambahkan persentase tertentu 
dari biaya pada semua barang dalam produk. Dalam strategi penentuan harga jual, pengelola usaha harus membuat tujuan penetapannya terlebih dahulu.

Tujuan penetapan harga jual yang tepat adalah untuk meningkatkan penjualan, memperbaiki dan mempertahankan market share, memperhatikan permintaan, mengusahakan mengembalikan investasi dengan pencapaian laba secara maksimal dan menentukan laba-rugi periodi (income determination), yaitu melalui proses mempertemukan harga pokok barang dijual dengan hasil penjualan dalam satu periode akuntansi. Perusahaan ingin menetapkan harga jual yang dapat menutupi sebuah biaya untuk produksi, distribusi, penjualan produk dan memberikan laba yang wajar bagi usaha dan risikonya.

Perusahaan sering dihadapkan pada berbagai risiko yang bersumber pada penetapan harga jual. Karena dapat mempengaruhi kemampuan perusahaan dalam mempertahankan kelangsungan kegiatannya. Bahkan perusahaan harus mengupayakan harga jual yang mampu menghasilkan laba dan daya saing yang wajar. Harga jual yang baik mengambarkan antisipasi perusahaan terhadap usaha untuk mempertinggi keuntungan yang diperoleh perusahaan. Dalam hal ini, ada beberapa faktor yang dipertimbangkan dalam penetapan harga jual, yaitu: (1) Berapa besar keuntungan yang diharapkan; (2) Stabilitas penjualan;(3) Stabilitas keuntungan, dan (4) Berapa besar risiko kebangkrutan yang dihadapi. Selain itu, banyak faktor yang mempengaruhi penetapan harga jual, diantaranya biaya penjualan dan laba perusahaan.

Kendala yang dihadapi dalam penetapan harga jual hingga ketingkat yang optimal adalah persoalan ketersediaan sumber dana dan biaya dari dana yang bersangkutan. Serta persoalan kenaikan harga bahan pokok itu sendiri. Memperhitungkan harga jual harus disertai dengan perhitungan harga pokok penjualan yang tepat agar tidak mengalami kerugian. Dalam situasi kenaikan harga bahan baku dan penolongnya, maka strategi hargalah yang dilakukan agar usaha bisa terus berjalan. Meskipun laba yang diperoleh perusahaan besar maupun kecil tergantung pada bagaimana perusahaan dapat mengendalikan proses dan luas produksinya serta menentukan harga jualnya.

Perhitungan harga pokok penjualan sangatlah penting bagi perusahaan, karena perhitungan harga pokok penjualan yang terlalu tinggi akan menyebabkan harga jual yang tinggi pula, sehingga tidak akan terjangkau oleh daya beli konsumen atau setidak-tidaknya akan mengurangi permintaan akan barang atau jasa. Penurunan permintaan barang atau jasa dari konsumen bila tidak diimbangi oleh kemampuan dari bagian pemasaran untuk mencari pelanggan baru akan mengakibatkan produksi dan laba perusahaan menurun karena harga pokok penjualan meningkat akibat dari biaya tetap.

Kimia Farma Apotek No. 66 Luwuk adalah salah satu unit dari PT. Kimia Farma Apotek Tbk, yang merupakan perusahaan dagang bergerak dibidang penjualan obatobatan dan kefarmasian. Dalam upaya peningkatan laba, Kimia Farma No. 66 Luwuk cenderung mengalami kendala seperti ketersediaan barang dagangan sehingga mengakibatkan meningkatnya harga pokok penjualan.

Kenaikan harga pokok penjualan inilah yang menjadi pemicu terhadap penurunan laba yang diperoleh Kimia Farma No. 66 Luwuk. Dengan demikian, penelitian ini dilakukan dengan judul "Analisis Harga Pokok Penjualan Pada Laba Di Apotek Kimia Farma 66 Luwuk". Hal tersebut dilakukan dengan pertimbangan bahwa penetapan harga jual merupakan masalah penting bagi setiap perusahaan dagang, karena baik buruknya akan mempengaruhi langsung terhadap laba yang dicapai perusahaan. 
Berdasarkan latar belakang yang telah dikemukakan di atas, maka rumusan masalah adalah "Apakah Penentuan Harga Pokok Penjualan Pada Apotek Kimia Farma No. 66 Luwuk Telah Memperoleh Laba Optimal?".

Tujuan penelitian, adalah: (1) Untuk mengetahui penentuan harga pokok penjualan di Apotek Kimia Farma No.66 Luwuk; (2) Untuk mengetahui apakah laba yang diperoleh sudah optimal dalam penentuan harga pokok penjualan.

\section{KAJIAN TEORI}

Pengertian Harga Pokok Penjualan. Perhitungan harga pokok penjualan sangatlah penting bagi perusahaan, karena perhitungan harga pokok penjualan yang terlalu tinggi akan menyebabkan harga jual yang tinggi pula, sehingga tidak akan terjangkau oleh daya beli konsumen atau setidak-tidaknya akan mengurangi permintaan akan barang atau jasa. Penurunan permintaan barang atau jasa dari konsumen bila tidak diimbangi oleh kemampuan dari bagian pemasaran untuk mencari pelanggan baru akan mengakibatkan produksi dan laba perusahaan menurun karena harga pokok penjualan meningkat akibat dari biaya tetap.

Menurut Supriyono dalam Macpal dkk., (2014 : 1497). Menyatakan bahwa "Harga perolehan atau harga pokok adalah jumlah yang dapat diukur dalam satuan uang dalam bentuk kas yang dibayarkan, atau nilai aktiva lainnya yang diserahkan /dikorbankan, atau nilai jasa yang diserahkan/dikorbankan, atau hutang yang timbul, atau tambahan modal". Menurut Purba dalam Widayawati (2013 : 194) menyatakan bahwa "Harga jual adalah sejumlah nilai yang ditukar oleh konsumen dengan manfaat dan memiliki atau menggunakan produk atau jasa yang nilainya ditetapkan oleh pembeli dan penjual untuk satu harga yang sama terhadap semua pembeli."

Suwardjono (2013 : 233) menyatakan pendapat yang berbeda yaitu, "makna harga pokok penjualan sebenarnya adalah harga dari pokok penjualan yang bermakna barang yang terjual. Namun, pokok tiba-tiba berubah fungsinya menjadi penjelas harga sehingga timbul harga pokok. Jadi, harga pokok merupakan istilah yang sangat rancu karena diturunkan dari istilah yang rancu lagi yaitu harga pokok penjualan. Istilah beban pokok penjualan makin rancu lagi. Beban pokok penjualan berarti pengurangan pokok penjualan. Ini berarti biaya administrasi dan penjualan dipandang tidak pokok dan ini bertentangan dengan praktik bisnis modern saat ini. Mungkin saja harga pokok penjualan dipakai sebagai padan kata cost of sales. Akan tetapi, cost of sales memberi kesan sebagai semua kos dalam rangka mendatangkan penjualan".

Elemen Harga Pokok Penjualan. Struktur dasar harga pokok penjualan terdiri dari tiga elemen besar saja yaitu meliputi, Persediaan (inventory), Tenaga kerja Langsung (Direct Labor Cost), dan Overhead Cost. Pertama. Persediaan (inventory). Dalam perusahaan dagang, elemen persediaan hanya terdiri dari persediaan barang jadi saja atau yang di kenal inventory. Sedangkan perusahaan manufaktur persediaannya terdiri dari persediaan bahan baku (Raw materials), persediaan barang dalam proses (WIP = Work In Process), persediaan barang jadi (inventory). Elemen Persediaan yang dimaksudkan dalam hal ini adalah besarnya persediaan terjual maka perlu mengetahui unsur-unsur persediaan antara lain : (1) Persediaan Awal. Persediaan awal merupakan persediaan yang tersedia pada awal suatu periode atau tahun buku berjalan. Saldo persediaan awal perusahaan terdapat pada neraca saldo periode berjalan atau pada neraca awal perusahaan atau laporan neraca 
tahunan sebelumnya. Artinya persediaan tersebut telah ada sebelum aktivitas periode ini dimulai.(2) Pembelian. Pembelian yang dimaksudkan adalah cost yang terjadi, sehingga besarnya nilai pembelian yang diakui hanya sebesar cost yang timbul saja, diwujudkan dengan pengeluaran kas atau pengakuan utang dagang. Sehingga nilai pembelian yang diakui adalah sebesar nilai bersihnya (net purchase) saja. Hal ini perlu ditegaskan karena dalam praktek bisnis, seringkali perusahaan sebagai pembeli, baik itu pembelian barang jadi (untuk perusahaan dagang) maupun pembelian bahan baku (perusahaan manufaktur) memperoleh potongan harga (discount), bisa juga terjadi pengembalian barang kepada pihak penjual (return). Artinya Untuk memperoleh pembelian bersih (net purchase), perusahaan dalam melakukan pembelian baik secara tunai maupun secara kredit, ditambah dengan biaya angkut pembelian serta dikurangi dengan potongan pembelian (discount) dan retur pembelian yang terjadi.(3) Persediaan Akhir. Persediaan akhir merupakan persediaan pada akhir suatu periode atau tahun buku berjalan. Saldo persediaan akhir perusahaan akan diketahui dari data penyesuaian perusahaan pada ahir periode. (4)Persediaan Tersedia Untuk dijual. Harga pokok pembelian dari seluruh barang yg dibeli selama periode, ditambah dengan harga pokok persediaan yang ada pada awal periode (persediaan awal) merupakan jumlah harga pokok dari seluruh barang yang tersedia untuk dijual selama periode. Jumlah ini disebut harga pokok barang yang tersedia dijual.

Persediaan awal ditambah dengan harga pokok barang yang dibeli sama dengan harga pokok barang yang tersedia dijual, dan harga pokok barang yang tersedia dijual dikurangi persediaan akhir sama dengan harga pokok penjualan. Seperti terlihat dalam laporan laba-rugi, hubungan ini dapat diringkas sebagai berikut :

Harga pokok barang yang tersedia dijual $=$ Persediaan awal + Pembelian barang

Harga pokok penjualan $=$ Harga pokok barang tersedia dijual - Persediaan akhir

Laba kotor penjualan $=$ Penjualan bersih - Harga pokok penjualan

Kedua. Tenaga kerja Langsung (Direct Labor Cost). Tenaga kerja langsung adalah upah yang dibayarkan kepada tenaga kerja yang langsung terlibat pada proses pengolahan barang dagangan. Dikatakan Direct Labor Cost hanya jika besarnya upah yang dibayarkan tergantung pada jumlah output product yang dihasilkan. Yang termasuk kelompok tenaga kerja langsung adalah tenaga kerja yang dibayar berdasarkan upah satuan atau upah harian/jam. Dalam hal ini tenaga kerja dibayar dengan upah satuan, tentu dengan jelas bisa kita lihat bahwa upah tenaga kerja tersebut dapat dibebankan langsung pada product yang dihasilkan. Jika upah yang dibayarkan berdasarkan jumlah jam kerja, maka biasanya perusahaan telah menentukan jumlah (satuan) yang harus dihasilkan untuk tenggang waktu tertentu (per jam atau per hari). Sehingga pada akhir perhitungan, dapat diketahui berapa direct labor cost untuk akumulasi product yang dihasilkan. Pada perusahaan pedagang kecil (small wholesaler atau retailer) direct labor cost sulit untuk bisa di alokasikan dengan semestinya. Sehingga direct labor cost hanya bisa kita temukan pada perusahaan-perusahaan manufaktur atau pertambangan. Ketiga. Overhead Cost adalah cost yang timbul selain dari kedua elemen diatas, yang biasanya disebut dengan indirect cost, jenis tentu saja bervariasi, tergantung jenis usaha, skala usaha dan jenis sumberdaya 
yang dipakai oleh perusahaan. Yang sering ditemui pada usaha manufaktur atau dagang adalah: (a) Sewa (Rental Cost);(b) Penyusutan Mesin dan Peralatan (Depreciation on Machineries \& Equipment); (c) Penyusutan Bangunan Pabrik (Factory's Building Depreciation); (d) Listrik, Air untuk Pabrik (Factory's Utilities); (e) Pemeliharaan Pabrik \& Mesin (Factory \& Machiniries Maintenance); (f) Pengemasan (Packaging/Bottling \& Labor Cost-nya); (g) Gudang (Warehousing Cost); (h) Sample Produksi (Pre-Production Sampling); (i) Ongkos kirim (Inbound \& Outbound deliveries); (j) Container (Continer).

Metode Penentuan Harga serta Tujuan dalam Penetapan Harga Jual. Metode Penentuan Harga Jual. Harga merupakan suatu hal penting, dimana harga merupakan komponen besar dari kepuasan konsumen. Nilai produk adalah apa yang dirasakan konsumen, jadi pembeli menetapkan nilai produk dari suatu produk. Dari sudut pandang produsen, harga tentu saja mempunyai peranan yang sangat penting, dimana harga ditentukan oleh berapa besar pendapatan yang ingin mereka peroleh. Banyaknya jumlah produk sangat dipengaruhi oleh harga jual produk yang dijual baik bagi produsen maupun konsumen.

Sedangkan harga jual adalah nilai yang dibebankan kepada pembeli atau pemakai barang atau jasa. Dalam hal ini, harga jual merupakan suatu yang dapat digunakan untuk mendapatkan sejumlah kombinasi dari barang atau jasa serta pelayanannya. Adapun tujuan pokok penentuan harga jual adalah mencapai target penjualan, memaksimumkan laba, meningkatkan penjualan dan mempertahankan atau memperluas pangsa pasar, dan menstabilkan harga.

Perusahaan-perusahaan mengubah strategi pemasarannya dengan meletakkan kepuasan konsumen sebagai prioritas utama dan esensil dalam mengarahkan kegiatankegiatan bisnis mereka. Perusahaan harus mampu menghasilkan produk dan jasa yang bermutu dengan harga yang sesuai dengan sumber daya yang telah dikorbankan untuk tetap dapat bertahan di pangsa pasar.

Perusahaan-perusahaan berlomba untuk menghasilkan produk atau jasa yang bermutu dengan harga yang terjangkau dengan demikian akan terjadi persaingan yang sehat dan sangat kompetitif. Menurut Mulyadi (1991 : 197) menyatakan bahwa Ada empat metode penentuan harga jual, yaitu: (a) Penentuan harga jual normal (Normal Pricing). Metode penentuan harga jual normal seringkali disebut dengan istilah cost-plus pricing, yaitu penentuan harga jual dengan cara menambahkan laba yang diharapkan diatas biaya penuh masa yang akan datang untuk memproduksi dan memasarkan produk; (b) Penentuan Harga Jual dalam Cost-type Contract (Cost-type Contract Pricing). Cost-type Contract adalah kontrak pembuatan produk dan yang pihak pembeli setuju membeli produk atau jasa pada harga yang didasarkan pada total biaya yang sesungguhnya dikeluarkan oleh produsen ditambah dengan laba yang dihitung sebesar persentase tertentu dari total biaya yang sesungguhnya; (c) Penentuan Harga Jual Pesanan Khusus (Special order Pricing).Pesanan khusus merupakan pesanan yang diterima oleh perusahaan diluar pesanan regular perusahaan; (d) Penentuan harga jual produk yang dihasilkan perusahaan yang diatur dengan peraturan pemerintah.

Produk dan jasa yang dihasilkan untuk memenuhi kebutuhan pokok masyarakat luas seperti listrik, air, telepon, dan telegraf, transportasi dan jasa pos diatur dengan peraturan pemerintah. Harga jual produk dan jasa tersebut ditentukan berdasarkan biaya penuh masa yang akan datang ditambah dengan laba yang diharapkan. Harga yang ditentukan untuk 
sebuah produk akan mempengaruhi pendapatan perusahaan dan pada akhirnya tingkat laba.

Menurut Widyawati (2013 : 195) menyatakan bahwa perusahaan menentukan harga jual produknya dengan tiga dasar pertimbangan yaitu biaya produksi, suplai perusahaan dan harga persaingan. Pertama. Penentuan harga berdasarkan biaya produksi. Pada strategi ini perusahaan menentukan harga untuk sebuah produk dengan mengestimasi biaya per unit untuk memproduksi produk tersebut dan menambahkan suatu kenaikkan. Jika metode ini digunakan perusahaan harus mencatat semua biaya yang melengkapi produksi sebuah produk dan diupayakan agar harga tersebut dapat menutupi semua biaya tersebut. Bagi produk atau jasa harga harus cukup rendah agar dapat mencapai volume tingkat penjualan yang tinggi sehingga biaya produksi mengalami penurunan. Kedua. Penentuan harga berdasarkan suplai persediaan. Pada umumnya perusahaan cenderung menurunkan harga jika mereka harus mengurangi persediaan. Ketiga. Penentuan harga berdasarkan harga pesaing. Penentuan harga berdasarkan harga pesaing dibagi atas tiga yaitu: (a) Penentuan harga penetrasi, dimana perusahaan menentukan harga yang lebih rendah dari harga pesaing agar dapat menembus pasar; (b) Penentuan harga defensive, dimana perusahaan menurunkan harga produk untuk mempertahankan pangsa pasarnya; (c) Penentuan harga prestise, ditentukan dengan tujuan untuk memberikan kesan terbaik bagi produk perusahaan.

Diharapkan manajemen perusahaan perusahaan dapat mengambil keputusan yang tepat dalam menetapkan harga jual produk atau jasa perusahaan mereka. Melalui strategi penetapan harga dapat membentuk citra perusahaan, persepsi yang sering berlaku bahwa harga yang mahal mencerminkan kualitas yang tinggi.

Tujuan Penetapan Harga Jual. Tujuan dalam penetapan harga jual adalah untuk meningkatkan penjualan, memperbaiki dan mempertahankan market share, memperhatikan permintaan, mengusahakan mengembalikan investasi dengan pencapaian laba secara maksimal dan menetukan laba-rugi periodi (income determination), yaitu melalui proses mempertemukan harga pokok barang dijual dengan hasil penjualan dalam satu periode akuntansi. Perusahaan ingin menetapkan harga jual yang dapat menutupi sebuah biaya untuk produksi, distribusi, penjualan produk dan memberikan laba yang wajar bagi usaha dan risikonya. Widyawati (2013 : 197) menyatakan bahwa ada beberapa tujuan penetapan harga yaitu: (1) Untuk mendukung strategi bauran pemasaran secara keseluruhan; (2) Mendapatkan keuntungan sebesar-besarnya dengan menetapkan harga yang kompetitif; (3) Mempertahakan perusahaan dari marjin keuntungan yang didapat perusahaan akan digunakan untuk biaya operasional perusahaan; (4) Menggapai ROI perusahaan pasti menginginkan balik modal dari investasi yang ditanam pada perusahaan; (5) Menguasai pangsa pasar dengan menetapkan harga lebih rendah dibandingkan produk pesaing;(6) Mempertahankan status ketika perusahaan memiliki pasar tersendiri.

Persediaan dalam Harga Pokok Penjualan. Menurut Juan \& Ersa (2012: 152) menyatakan bahwa penentuan nilai persediaan diakhir tahun buku akan berpengaruh secara langsung terhadap penentuan harga pokok penjualan selama satu tahun tersebut. Hal ini karena nilai persediaan akhir dan harga pokok penjualan didapatkan dari hasil alokasi sejumlah tetap biaya barang yang tersedia untuk dijual (yang merupakan jumlah dari persediaan awal dan pembelian tahun berjalan). 
Pertama. Sistem persediaan periodik. Dalam sistem persediaan periodik (periodic inventory system-berkala), nilai persediaan akhir ditentukan melalui pemeriksaan stok fisik (physical stock-take).

$$
\text { Harga pokok penjualan }=\begin{aligned}
& \text { Nilai persediaan awal }+ \text { Biaya barang yang } \\
& \text { dibeli/dibuat }- \text { Nilai persediaan akhir }
\end{aligned}
$$

Kedua. Sistem persediaan perpetual. Dalam sistem perpetual (perpetual inventory system), biaya persediaan akhir dan harga pokok penjualan selama tahun berjalan dapat ditentukan secara langsung dari catatan akuntansi. Namun, jika ada ketidakcocokan antara biaya persediaan pada catatan akuntansi dan nilai persediaan yang ditentukan melalui pemeriksaan stok fisik, maka jumlah persediaan pada catatan akuntansi harus disesuaikan. Harga pokok penjualan pada catatan akuntansi juga harus disesuaikan.

Biaya persediaan ditentukan melalui dua proses: (a) Menentukan biaya pembelian/pembuatan barang (biaya persediaan atau inventoriable cost) dan (b) Mengalokasikan jumlah nilai persediaan awal dan biaya pembelian/pembuatan barang ke biaya persediaan akhir dan harga pokok penjualan, dengan menggunakan rumus biaya.

Biaya persediaan meliputi semua biaya pembelian, biaya konversi, dan biaya lain yang timbul hingga persediaan berada dalam kondisi dan tempat yang siap dijual atau dipakai. (present location and condition)

Pengertian Laba. Salah satu tujuan utama perusahaan yang penting untuk dicapai adalah pencapaian laba optimum. Pencapaian laba dirasa penting karena berkaitan dengan berbagai konsep akuntansi antara lain kesinambungan perusahaan (going concern) dan perluasan perusahaan, serta mengembangkan usahanya ketingkat yang lebih tinggi atau ketingkat yang lebih baik. Untuk menjamin agar usaha perusahaan mampu menghasilkan laba, maka manajemen perusahaan harus merencanakan dan mengendalikan dengan baik dua faktor penentu laba yaitu pendapatan dan biaya.

Masalah yang berkaitan dengan laba adalah menentukan konsep laba secara tepat untuk pelaporan keuangan sehingga angka laba merupakan angka yang bermakna (meaningful) baik secara intuitif maupun ekonomik bagi berbagai pemakai statemen keuangan. Pemaknaan atau pendefinisian laba mempunyai implikasi terhadap pengukuran dan penyajian laba. Karena akuntansi secara umum menganut konsep kos historis, asas akrual, dan konsep perbandingan, laba akuntansi yang sekarang dianut dimaknai sebagai selisih antara pendapatan dan biaya. Berikut ini beberapa teori mengenai definisi laba.

Menurut Juan \& Wahyuni (2012: 11) menyatakan bahwa "Penghasilan neto (laba) sering kali digunakan sebagai ukuran kinerja. Definisi penghasilan (income) meliputi pendapatan (revenue) maupun keuntungan (gains). Pendapatan timbul dalam pelaksanaan aktivitas perusahaan yang biasa dan dikenal dengan sebutan yang berbeda, seperti penjualan, penghasilan jasa, bunga, deviden, royalti, dan sewa. Keuntungan mencerminkan pos lainnya, misalnya keuntungan atas penjualan aset tetap".

Menurut Rainbow \& Kinney (2011: 113) menyatakan bahwa "Laba semu (phantom profits) merupakan laba perhitungan biaya serapan yang sementara, disebabkan oleh lebih banyak memproduksi persediaan dari pada menjualnya".

Menurut Godfrey dkk., dalam Suwardjono (2011: 464) menyatakan bahwa "Laba dimaknai sebagai imbalan atas upaya perusahaan menghasilkan barang dan jasa. Ini berarti 
laba merupakan kelebihan pendapatan di atas biaya (kos total yang melekat kegiatan produksi dan penyerahan barang/ jasa)".

Menurut Paton \& Littleton dalam Suwardjono (2011: 464) menyatakan bahwa "Laba adalah kenaikan aset dalam suatu periode akibat kegiatan produktif yang dapat dibagi atau didistribusi kepada kreditor, pemerintah, pemegang saham (dalam bentuk bunga, pajak, deviden) tanpa mempengaruhi keutuhan ekuitas pemegang saham semula”. Selain income, dikenal pula earnings yang juga disebut laba. Earnings lebih bermakna sebagai laba yang diakumulasi selama beberapa periode walaupun earnings juga digunakan untuk menunjuk laba periode seperti earnings per share. Dalam statemen laba-rugi, income lebih umum digunakan karena tidak lebih luas cakupannya (lebih komprehensif). Dan lebih formal dari pada earnings. Earnings hanyalah jumlah antara sebelum diperoleh laba bersih/komprehensif.

Hubungan Harga Pokok Penjualan Dengan Laba. Menurut Munawir (2010: 216) menyatakan bahwa Perubahan dalam laba kotor perlu dianalisa untuk mengetahui sebabsebab perubahan tersebut, baik perubahan yang menguntungkan (kenaikan) maupun perubahan yang tidak menguntungkan (penurunan) sehingga akan dapat diambil kesimpulan dan atau diambil tindakan seperlunya untuk periode-periode berikutnya.

Pada dasarnya perubahan laba kotor itu disebabkan oleh dua faktor, yaitu faktor penjualan dan faktor harga pokok penjualan. Besar kecilnya hasil penjualan dipengaruhi oleh kuantitas atau volume produk yang dapat dijual dan harga jual per satuan produk tersebut. Oleh karna itu perubahan laba kotor karena adanya perubahan hasil penjualan disebabkan adanya: (a) Perubahan harga jual per satuan produk; (b) Perubahan kuantitas atau volume produk yang dijual/dihasilkan.

Faktor harga pokok penjualan juga dipengaruhi oleh kuantitas produk yang dijual/dihasilkan tersebut, oleh karena itu perubahan laba yang disebabkan oleh adanya perubahan harga pokok penjualan dapat disebabkan oleh: (a) Perubahan harga pokok ratarata per satuan; (b) Perubahan kuantitas atau volume produk yang dijual.

Perubahan harga baik itu merupakan penurunan dan kenaikan yang disebabkan oleh faktor harga jual tidak dapat digunakan sebagai pengukur kegiatan bagian penjualan, karena hal ini dapat disebabkan oleh faktor ekstern perusahaan. Perubahan harga jual ditentukan oleh keadaan pasar yang sulit dikendalikan oleh perusahaan, lain halnya dengan perubahan kuantitas produk yang dijual. Suatu perubahan laba yang disebabkan oleh adanya perubahan kuantitas atau volume barang yang dijual mempunyai hubungan langsung dengan kegiatan bagian penjualan. Kenaikan laba karena adanya kenaikan volume yang dijual berarti bagian penjualan bekerja lebih aktif (dengan anggapan bahwa biaya pemasaran tetap maka perubahan laba yang disebabkan oleh kenaikan volume penjualan berarti perusahaan semakin efisien dalam operasinya).

Penurunan laba kotor yang disebabkan oleh naiknya harga pokok penjualan menunjukkan bagian produksi telah bekerja tidak efisien. Kenaikan ini kemungkinan disebabkan oleh faktor ekstern, misalnya adanya kenaikan harga bahan, tingkat upah atau kenaikan harga-harga secara umum yang tidak dapat dikendalikan oleh perusahaan, atau mungkin disebabkan oleh faktor intern yaitu adanya in efisiensi atau pemborosanpemborosan.

Menurut Munawir (2010: 218) menyatakan bahwa perubahan laba bruto pada dasarnya disebabkan oleh 4 faktor, yaitu: 
Perubahan harga jual (Sales Price Variance), yaitu adanya perubahan antara harga jual yang sesungguhnya dengan harga jual yang dibudgetkan atau harga jual tahun sebelumnya. Perubahan laba kotor yang disebabkan adanya perubahan harga jual dapat ditentukan dengan rumus:

(Harga jual menurut realisasi atau yang sesungguhnya - harga jual budget atau tahun sebelumnya) x kuantitas produk yang sesungguhnya dijual tahun ini.
Atau :

$$
\left(\mathbf{H j}_{2}-\mathbf{H j}_{\mathbf{1}}\right) \mathbf{K}_{2}
$$

$\mathbf{H j}_{1}$ = harga jual per satuan produk yang dibudgetkan atau tahun sebelumnya

$\mathbf{H j}_{\mathbf{2}} \quad$ = harga jual per satuan produk yang sesungguhnya

$\mathbf{K}_{2} \quad$ = kuantitas atau volume produk yang sesungguhnya dijual tahun ini

Apabila $\left(\mathbf{H} \mathbf{j}_{2}-\mathbf{H} \mathbf{j}_{1}\right)$ menunjukkan/menghasilkan angka positif berarti ada kenaikan harga yang berarti menunjukkan keadaan yang menguntungkan, sebaliknya bila negatif berarti ada penurunan harga jual dan menunjukkan keadaan yang merugikan.

Kuantitas produk yang dijual (Sales Volume Variance), yaitu adanya perbedaan antara kuantitas produk yang direncanakan/tahun sebelumnya dengan kuantitas produk yang sesungguhnya dijual (direalisir). perubahan laba kotor yang disebabkan oleh perubahan kuantitas/volume produk yang dijual dapat ditentukan dengan rumus :

$$
\left(\mathbf{K}_{2}-\mathbf{K}_{1}\right) \mathbf{H j}_{\mathbf{1}}
$$

$\mathbf{K}_{2}=$ Kuantitas penjualan yang sesungguhnya direalisir tahun ini

$\mathbf{K}_{\mathbf{1}}=$ Kuantitas penjualan yang dibudgetkan atau tahun sebelumnya

$\mathbf{H j}_{\mathbf{1}}=$ Harga jual per satuan produk yang dibudgetkan atau tahun sebelumnya sebagai standar

Bila $\left(\mathbf{K}_{2}-\mathbf{K}_{\mathbf{1}}\right)$ menghasilkan angka positif menunjukkan bahwa kuantitas produk yang sesungguhnya dijual lebih besar dari pada yang direncanakan, hal ini menunjukkan keadaan yang menguntungkan atau bagian penjualan bekerja lebih baik, sebaliknya bila menghasilkan angka negatif berarti penjualan turun dan menunjukkan keadaan yang merugikan.

Perubahan harga pokok penjualan per satuan produk (Cost Price Variance), yaitu adanya perbedaan antara harga pokok penjualan per satuan produk (Unit Cost) menurut budget /tahun sebelumnya dengan harga pokok yang sesungguhnya. Untuk menentukan besarnya perubahan laba kotor yang disebabkan adanya perubahan harga pokok penjualan per satuan produk dapat ditentukan dengan rumus:

\section{$\left(\mathrm{HPP}_{2}-\mathrm{HPP}_{1}\right)$}

$\begin{array}{ll}\mathbf{H P P}_{2} & =\text { Harga pokok penjualan yang sesungguhnya } \\ \mathbf{H P P}_{1} & =\text { Harga pokok penjualan menurut budget/tahun sebelumnya } \\ \mathbf{K}_{2} & =\text { kuantitas produk yang sesungguhnya dijual }\end{array}$

Atau: (Harga pokok penjualan yang sesungguhnya - harga pokok penjualan yang dibudgetkan atau tahun sebelumnya) x kuantitas produk yang dijual. 
Apabila $\left(\mathbf{H P P}_{2}-\mathbf{H P P}_{1}\right)$ menghasilkan angka positif berarti HPP mengalami kenaikan, kenaikan dalam sektor biaya menunjukkan keadaan yang merugikan, sebaliknya bila hasil negatif berarti biaya mengalami penurunan yang berarti pula menunjukkan keadaan yang menguntungkan.

Perubahan kuantitas harga pokok penjualan (Cost Volume Variance), yaitu adanya perubahan harga pokok penjualan karena adanya perubahan kuantitas /volume yang dijual atau diproduksi.

Rumus untuk menentukan besarnya perubahan laba bruto karena perubahan kuantitas harga pokok penjualan adalah:

(Kuantitas yang sesungguhnya - kuantitas menurut budget atau tahun sebelumnya) $\mathrm{x}$ harga pokok menurut budget atau tahun sebelumnya.

$\begin{array}{ll}\text { Atau : } & \left(\mathrm{K}_{2}-\mathrm{K}_{1}\right) \mathrm{HPP}_{1} \\ & \end{array}$

$\mathbf{K}_{2} \quad=$ kuantitas produk yang sesungguhnya dijual/dihasilkan.

$\mathbf{K}_{\mathbf{1}} \quad=$ kuantitas produk menurut budget/tahun Sebelumnya $\mathrm{HPP}_{1}=$ harga pokok penjualan per satuan barang menurut budget.

Apabila $\left(\mathbf{K}_{\mathbf{2}}-\mathbf{K}_{\mathbf{1}}\right)$ menghasilkan angka positif berarti kuantitas yang dijual/produksi bertambah (mengalami kenaikan), apabila kuantitas bertambah maka harga pokok penjualan akan mengalami kenaikan pula dan bertambahnya harga pokok penjualan menunjukkan keadaan yang tidak menguntungkan (merugikan). Sebaliknya bila hasilnya negatif berarti ada penurunan biaya dan menunjukkan keadaan yang menguntungkan.

Jenis Laba dan Faktor yang Mempengaruhi Laba. Tatang Sontani (2014: 1) menyatakan bahwa ada beberapa definisi umum penggunaan laba adalah sebagai berikut: (1) Laba sebelum bunga, pajak, depresiasi, dan amortisasi (EBITDA) sama dengan biaya dikurangi pendapatan penjualan barang yang dijual dan semua biaya, kecuali untuk bunga, amortisasi, penyusutan dan pajak; (2) Laba sebelum bunga dan pajak (EBIT), atau laba operasi, sama dengan biaya dikurangi pendapatan penjualan barang yang dijual dan semua biaya kecuali untuk bunga dan pajak. Ini adalah surplus yang dihasilkan oleh operasi; (3) Laba sebelum pajak (EBT) atau laba bersih sebelum pajak, sama dengan biaya dikurangi pendapatan penjualan barang yang dijual dan semua biaya kecuali untuk pajak. Hal ini juga dikenal sebagai pra-pajak penghasilan book (PTBI), pendapatan operasional bersih sebelum pajak, atau hanya pendapatan sebelum pajak; (4) Laba kotor sama dengan biaya dikurangi pendapatan penjualan barang yang dijual (HPP), sehingga menghilangkan hanya bagian dari biaya yang dapat ditelusuri langsung ke produksi atau pembelian barang.

Menurut Mulyadi dalam Mahira (2013: 1) menyatakan bahwa didalam memperoleh laba diharapkan perusahaan perlu melakukan suatu pertimbangan khusus dalam memperhitungkan laba yang akan diharapkan dengan memperhatikan faktor-faktor yang mempengaruhi laba tersebut, antara lain: (1) Biaya, Biaya yang timbul dari perolehan atau mengolah suatu produk atau jasa akan mempengaruhi harga jual produk yang bersangkutan; (2) Harga jual, harga jual produk dan jasa akan mempengaruhi besarnya volume penjualan produk atau jasa yang bersangkutan; (3) Volume penjualan dan produksi, besarnya volume penjualan berpengaruh terhadap volume produksi produk dan 
jasa tersebut, selanjutnya volume produksi akan mempengaruhi besar kecilnya biaya produksi.

Konsep Laba Optimal. Menurut Sofyan (2011: 1) menyatakan bahwa untuk memaksimalkan laba yang diperoleh bisa dicapai melalui bermacam-macam cara, antara lain ialah melalui efisiensi disemua bidang, seperti produksi, sumber daya manusia, maupun keuangan. Tujuan utama dari suatu usaha adalah mendapatkan keuntungan sebesar-besarnya, Untuk mencapai tujuan tersebut tidak terlepas dari faktor manusia sebagai pengendali semua fungsi. Akan tetapi tidak hanya faktor manusia saja, faktor pendukung lain juga berpengaruh terhadap perolehan laba, yaitu antara lain faktor jumlah produk, modal, dan upah tenaga kerja.

Dalam praktek pemaksimuman keuntungan, ada sebagian perusahaan yang melakukannya dengan cara menekan keuntungan yaitu dengan menekan penjualannya (hasil produksi) ada pula yang memasukkan unsur politik didalam penentuan tingkat produksi yang akan tercapai. Jadi, setiap perusahaan memiliki kriteria sendiri dalam memaksimumkan laba yang akan diperolehnya. Keuntungan akan diperoleh jika hasil penjualannya lebih besar dari ongkos produksi, dan kerugian akan terjadi apabila hasil penjualan lebih sedikit dari ongkos produksi. Dalam usahanya untuk memproduksi barang-barang yang diperlukan dalam masyarakat, dan memperoleh keuntungan maksimum dari usaha tersebut.

Efisiensi di bidang keuangan memberikan pengaruh pada operasi perusahaan, sehingga akan meningkatkan efisiensi biaya operasional dan efisiensi investasi yang pada akhirnya akan dapat meningkatkan laba perusahaan. Dengan memaksimalkan laba, perusahaan dapat mempertahankan pertumbuhan perusahaannya sehingga dapat bersaing dengan perusahaan lain karena laba tersebut dapat ditanam kembali dan digunakan untuk mempertahankan atau meningkatkan pertumbuhannya.

Perkembangan dunia usaha yang semakin pesat dengan pembangunan teknologi yang semakin maju membawa pengaruh yang besar terhadap produksi yang dihasilkan oleh industri. Seperti halnya industri lain, setiap industri juga bertujuan untuk memperoleh laba guna melangsungkan hidupnya. Laba yang dihasilkan tidak terlepas dari beberapa faktor antara lain jumlah hasil produksinya, modal, dan upah tenaga kerja.

Kimia Farma Apotek No.66 Luwuk adalah salah satu cabang unit Apotek dari PT. Kimia Farma Apotek tbk. Kimia Farma Apotek pada umumnya berfungsi sebagai pelayanan kefarmasian seperti informasi tentang penggunaan obat serta pelayanan obatobatan seperti menjual obat yang berkualitas dengan harga yang dapat dijangkau oleh konsumen dan tentunya pasti berizin dari Badan Pegawasan Obat dan Makanan (BPOM). Pelayanan obat-obatan yang dilakukan seperti pelayanan Resep dokter, Upds (obat bebas terbatas), dan HV (obat bebas). Jenis obat yang dijual seperti tablet, kaplet, kapsul, sirup, suppotoria, ampul, infus, alat kesehatan dan lain-lain.

Dalam pemesanan barang dagangan, Kimia Farma Apotek No.66 Luwuk menggunakan tehnik pemesanan pareto A yang berupa obat-obatan Fast Moving dan pareto B untuk obat-obatan Slow Moving. Pemesanan barang dagangan dilakukan seminggu sekali sesuai dengan kebutuhan apotek. Untuk memesan barang dagangan, Kimia Farma Apotek No. 66 Luwuk menggunakan Sistem Aplikasi KIS (Kimia Farma Information System). Dalam perhitungan harga jual, aplikasi ini sudah mencakup harga dasar barang dikurangi diskon ditambahkan Pajak Pendapatan Nasional (PPN). Sehingga 
diperoleh harga jual yang menjadi acuan Kimia Farma Apotek No.66 Luwuk dalam penjualan barang dagangan.

Dari penjualan barang dagangan tersebut, laba yang diperoleh Kimia Farma Apotek No. 66 Luwuk belumlah optimal, bahkan sering terjadi penurunan laba atau kerugian, hal ini timbul karena ketersediaan barang dagangan sehingga memicu meningkatnya harga pokok penjualan.

Berikut ini gambar kerangka pemikiran sebagai berikut :

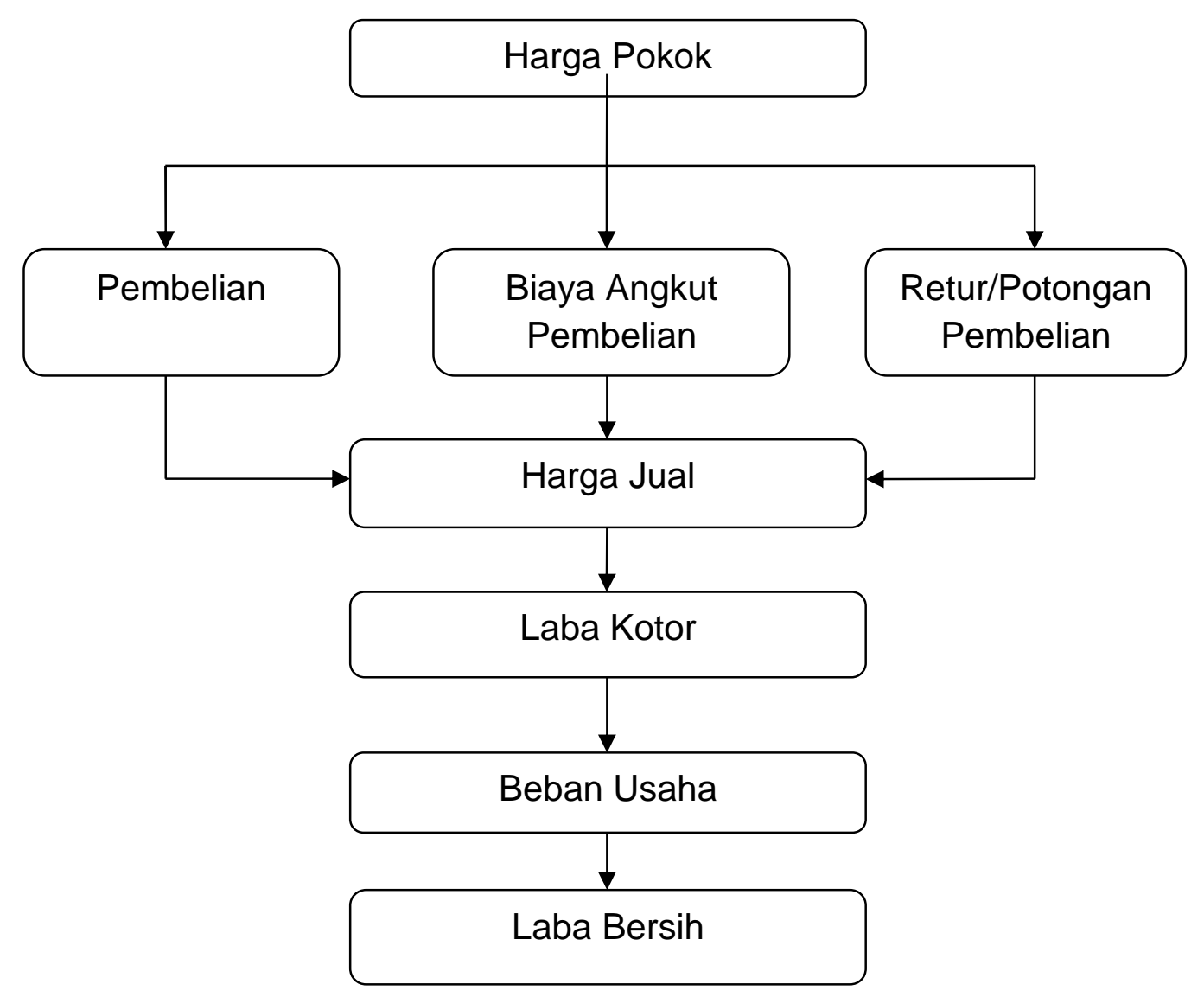

Gambar 1. Kerangka Pikir penelitian

Hipotesis. Berdasarkan rumusan masalah, maka hipotesisnya adalah: diduga bahwa Apotek Kimia Farma No.66 Luwuk telah memperoleh laba yang optimal setelah penerapan harga pokok penjualan.

\section{METODE}

Penelitian ini dilakukan pada Kimia Farma Apotek No.66 Luwuk, dengan waktu penelitian mulai dari bulan Maret - Juli 2015.

Jenis Data: (1) Data Kuantitatif, yang dapat dihitung atau data yang berupa angka-angka seperti laporan keuangan, laporan laba-rugi dan harga pokok penjualan; (2) Data kualitatif, data yang 
tidak dapat dihitung atau data yang bukan berupa angka-angka seperti gambaran umum perusahaan dan struktur organisasi.

Sumber Data: Penelitian ini bersumber dari data primer yang diperoleh langsung dari pihak pertama yaitu Kimia Farma Apotek No.66 Luwuk dan data sekunder yang diperoleh dari kepustakaan.

Metode Analisis Data. Metode analisis yang digunakan adalah metode analisis deskriptif yaitu untuk mengetahui analisis penentuan harga pokok penjualan. Data-data tersebut dianalisis dengan menghitung data kuantitatif dan dinyatakan dengan data kualitatif untuk menginterpretasikan hasil perhitungan data tersebut dan menjawab masalah yang akan diteliti dan akhirnya ditarik kesimpulan dari pengolahan data tersebut. selanjutnya untuk mengetahui tentang harga pokok penjualan dan laba, penulis menggunakan metode harga pokok penjualan dan laba dengan rumus sebagai berikut :

Rumus untuk menghitung Harga Pokok Penjualan:

HPP = Barang tersedia untuk dijual (BTUD) - Persediaan akhir

BTUD $=$ Persediaan barang dagangan awal + Pembelian bersih

Laba Kotor $=$ Penjualan Bersih - Harga Pokok Penjualan.

Laba Bersih = Laba Kotor - Beban Usaha.

\section{HASIL DAN PEMBAHASAN}

Hasil Penelitian. Kimia Farma Apotek No. 66 Luwuk merupakan salah satu cabang outlet dari PT. Kimia Farma Apotek. Dalam kegiatannya sebagai pelayanan obat-obatan, perolehan laba yang optimal sangat diperlukan demi kesinambungan, serta mengembangkan Apotek ketingkat yang lebih tinggi atau ketingkat yang lebih baik. Adapun yang terkait dengan Laba pada Kimia Farma Apotek No.66 Luwuk terdiri dari, Penjualan, Pembelian, Harga Pokok Penjualan, dan Persediaan Barang dagangan.

Kimia Farma Apotek No.66 Luwuk, dalam perhitungan persediaan menggunakan metode FIFO (First In First Out) dengan sistem persediaan periodik (periodic inventory system-berkala), nilai persediaan akhir ditentukan melalui pemeriksaan stok fisik (physical stock-take). Berikut ini adalah data persediaan dan pembelian bersih Kimia Farma Apotek No. 66 Luwuk.

Tabel 1. Persediaan Awal, Pembelian Bersih, dan Persediaan Akhir, Kimia Farma Apotek No. 66 Luwuk.

\begin{tabular}{ccccc}
\hline Tahun & Periode & Persed. Awal (Rp) & Pembelian (Rp) & Persed. Akhir (Rp) \\
\hline \multirow{2}{*}{2013} & Januari-Juni & 443.024 .000 & 1.025 .448 .000 & 348.360 .000 \\
& Juli-Desember & 443.024 .000 & 1.023 .452 .000 & 421.772 .000 \\
\multirow{2}{*}{2014} & Januari-Juni & 421.772 .000 & 127.348 .000 & 183.094 .000 \\
& Juli-Desember & 421.772 .000 & 237.411 .000 & 233.907 .000 \\
\hline
\end{tabular}

Sumber: Data Stock Opname dan Pembelian Kimia Farma Apotek No.66 2013-2014

Berdasarkan data pada Tabel 1, menunjukkan bahwa persediaan akhir Kimia Farma Apotek No. 66 Luwuk pada tahun 2013 sampai dengan 2014 mengalami fluktuaktif, demikian pula dengan pembelian bersih juga berfluktuaktif. 
Berikut ini adalah data Harga Pokok penjualan, Penjualan, dan Laba yang diperoleh dari Kimia Farma Apotek No. 66 Luwuk dari Tahun 2013-2014.

Tabel 2. Harga Pokok Penjualan, Penjualan, dan Laba Bersih Kimia Farma Apotek No. 66 Luwuk

\begin{tabular}{cccrc}
\hline Tahun & Periode & HPP $(\mathrm{Rp})$ & Penjualan $(\mathrm{Rp})$ & Laba Bersih $(\mathrm{Rp})$ \\
\hline \multirow{2}{*}{2013} & Januari-Juni & 1.120 .112 .000 & 1.517 .781 .000 & 288.710 .000 \\
& Juli-Desember & 1.044 .704 .000 & 1.368 .186 .000 & 219.712 .727 \\
\multirow{2}{*}{2014} & Januari-Juni & 366.026 .000 & 515.318 .000 & 70.383 .939 \\
& Juli-Desember & 425.276 .000 & 572.413 .000 & 68.467 .575 \\
\hline
\end{tabular}

Sumber: Data Laba Rugi Kimia Farma Apotek No. 66 Luwuk 2013-2014

Dari Tabel 2, menunjukkan bahwa Harga pokok penjualan Kimia Farma Apotek No. 66 Luwuk pada tahun 2013 sampai dengan 2014 mengalami fluktuaktif, demikian pula dengan laba berfluktuaktif sehingga terjadi penurunan laba yang cukup signifikan.

Pada dasarnya Harga Pokok penjualan berfungsi untuk menetapkan harga jual yang merupakan aspek penting dalam pencapaian laba optimum. Seperti halnya pada Kimia Farma Apotek No. 66 Luwuk, bahwa harga pokok penjualan sangat diperlukan untuk menentukan harga jual yang mempunyai daya saing pasar. Untuk mengetahui Harga Pokok penjualan pada Kimia Farma Apotek pada tahun 2013 sampai dengan 2014 adalah sebagai berikut :

Harga Pokok Penjualan. Tahun 2013 semester pertama:

Barang Tersedia Untuk Dijual $($ BTUD $)=$ Persediaan Awal + pembelian Bersih

$$
\begin{aligned}
& =\text { Rp.443.024.000 + Rp.1.025.448.000 } \\
& =\text { Rp.1.468.472.000 }
\end{aligned}
$$

Harga Pokok Penjualan $=$ BTUD - Persediaan Akhir

$$
\begin{aligned}
& =\text { Rp.1.468.472.000 - Rp.348.360.000 } \\
& =\text { Rp.1.120.112.000 }
\end{aligned}
$$

Dari perhitungan tersebut di atas, dapat diketahui bahwa harga pokok penjualan pada Kimia Farma Apotek No. 66 Luwuk semester pertama tahun 2013 sebesar Rp. 1.120.112.000.

Tahun 2013 semester kedua:

$$
\begin{aligned}
\text { Barang Tersedia Untuk Dijual (BTUD) }= & \text { Persediaan Awal + pembelian Bersih } \\
& =\text { Rp.443.024.000 + Rp.1.023.452.000 } \\
& =\text { Rp. } 1.466 .476 .000
\end{aligned}
$$

Harga Pokok Penjualan $=$ BTUD - Persediaan Akhir

$$
\begin{aligned}
& =\text { Rp.1.466.476.000 - Rp.421.772.000 } \\
& =\text { Rp.1.044.704.000 }
\end{aligned}
$$

Dari perhitungan tersebut di atas, dapat diketahui bahwa harga pokok penjualan pada Kimia Farma Apotek No. 66 Luwuk semester kedua tahun 2013 sebesar Rp. 1.044.704.000 
Tahun 204 semester pertama:

Barang Tersedia Untuk Dijual $($ BTUD) $=$ Persediaan Awal + pembelian Bersih $=$ Rp.421.772.000 + Rp.127.348.000 $=$ Rp.549.120.000

Harga Pokok Penjualan $=$ BTUD - Persediaan Akhir

$$
\begin{aligned}
& =\text { Rp.549.000.000 - Rp.183.094.000 } \\
& =\text { Rp.366.026.000 }
\end{aligned}
$$

Dari perhitungan tersebut di atas, dapat diketahui bahwa harga pokok penjualan pada Kimia Farma Apotek No. 66 Luwuk semester pertama tahun 2014 sebesar Rp. 366.026.000

Tahun 2014 semester kedua:

Barang Tersedia Untuk Dijual (BTUD) $=$ Persediaan Awal + pembelian Bersih

$$
\begin{aligned}
& =\text { Rp.421.772.000 +Rp.237.411.000 } \\
& =\text { Rn.659.183.000 }
\end{aligned}
$$

$$
\begin{aligned}
\text { Harga Pokok Penjualan }= & \text { BTUD }- \text { Persediaan Akhir } \\
& =\text { Rp.659.000.000 }- \text { Rp. } 233.907 .000 \\
& =\text { Rp. } 425.276 .000
\end{aligned}
$$

Dari perhitungan tersebut di atas, dapat diketahui bahwa harga pokok penjualan pada Kimia Farma Apotek No. 66 Luwuk semester kedua tahun 2014 sebesar Rp. 425.276.000.

\section{Laba}

Tahun 2013 semester pertama:

Laba Kotor $=$ Penjualan Bersih - Harga Pokok Penjualan.

$$
\begin{aligned}
& =\text { Rp.1.517.781.000 }- \text { Rp.1.120.112.000 } \\
& =\text { Rp.397.669.000 }
\end{aligned}
$$

Laba Bersih = Laba Kotor - Beban Usaha.

$$
\begin{aligned}
& =\text { Rp.397.669.000 }- \text { Rp.80.088.000 } \\
& =\text { Rp.317.581.000 }
\end{aligned}
$$

Dari perhitungan tersebut di atas, dapat diketahui bahwa laba bersih sebelum dikurangi pajak pada Kimia Farma Apotek No. 66 Luwuk semester pertama tahun 2013 sebesar Rp. 317. 581.000 .

Tahun 2013 semester kedua:

$$
\begin{aligned}
\text { Laba Kotor } & =\text { Penjualan Bersih }- \text { Harga Pokok Penjualan. } \\
& =\text { Rp.1.368.186.000 }- \text { Rp.1.044.704.000 } \\
& =\text { Rp.323.482.000 } \\
\text { Laba Bersih } & =\text { Laba Kotor }- \text { Beban Usaha. } \\
& =\text { Rp.323.482.000 }- \text { Rp.81.798.000 } \\
& =\text { Rp.241.684.000 }
\end{aligned}
$$


Dari perhitungan tersebut di atas, dapat diketahui bahwa laba bersih sebelum dikurangi pajak pada Kimia Farma Apotek No. 66 Luwuk semester kedua tahun 2013 sebesar Rp. 241.684.000.

Tahun 2014 semester pertama:

Laba Kotor $=$ Penjualan Bersih - Harga Pokok Penjualan.

$$
\begin{aligned}
& =\text { Rp. } 515.318 .000-\text { Rp.366.026.000 } \\
& =\text { Rp.149.292.000 }
\end{aligned}
$$

Laba Bersih = Laba Kotor - Beban Usaha.

$$
\begin{aligned}
& =\text { Rp.149.292.000 }- \text { Rp.71.869.667 } \\
& =\text { Rp.77.422.333 }
\end{aligned}
$$

Dari perhitungan tersebut di atas, dapat diketahui bahwa laba bersih sebelum dikurangi pajak pada Kimia Farma Apotek No. 66 Luwuk semester pertama tahun 2014 sebesar Rp. 77.422 .333

Tahun 2014 semester kedua:

Laba Kotor $=$ Penjualan Bersih - Harga Pokok Penjualan.

$$
\begin{aligned}
& =\text { Rp.572.413.000 }- \text { Rp.425.276.000 } \\
& =\text { Rp.147.137.000 }
\end{aligned}
$$

Laba Bersih = Laba Kotor - Beban Usaha.

$$
\begin{aligned}
& =\text { Rp.147.137.000 }- \text { Rp.71.822.667 } \\
& =\text { Rp.75.314.333 }
\end{aligned}
$$

Dari perhitungan tersebut di atas, dapat diketahui bahwa laba bersih sebelum dikurangi pajak pada Kimia Farma Apotek No. 66 Luwuk semester kedua tahun 2014 sebesar Rp. 75.314.333. Untuk lebih jelasnya harga pokok penjualan dan laba bersih sebelum dikurangi pajak pada Kimia Farma Apotek No.66 Luwuk Tahun 2013-2014 adalah sebagai berikut.

Tabel 3. Harga Pokok penjualan dan Laba Bersih Kimia Farma Apotek No. 66 Luwuk

\begin{tabular}{cccc}
\hline Tahun & Periode & Harga Pokok Penjualan $(\mathrm{Rp})$ & Laba Bersih $(\mathrm{Rp})$ \\
\hline \multirow{2}{*}{2013} & Januari-Juni & 1.120 .112 .000 & 317.581 .000 \\
& Juli-Desember & 1.044 .704 .000 & 241.684 .000 \\
\multirow{2}{*}{2014} & Januari-Juni & 366.026 .000 & 77.422 .333 \\
& Juli-Desember & 425.276 .000 & 75.314 .333 \\
\hline
\end{tabular}

Sumber: Data Olahan Tahun 2015

Dan berikut ini adalah data harga pokok penjualan dan laba bersih sebelum dikurangi pajak pada Kimia Farma Apotek No. 66 Luwuk. 
Tabel 4. Harga Pokok Penjualan dan Laba Bersih sebelum pajak Kimia Farma Apotek No. 66 Luwuk

Tahun 2013-2014

\begin{tabular}{cccc}
\hline Tahun & Periode & Harga Pokok Penjualan $(\mathrm{Rp})$ & Laba Bersih $(\mathrm{Rp})$ \\
\hline \multirow{2}{*}{2013} & Januari-Juni & 1.120 .112 .000 & 317.581 .000 \\
& Juli-Desember & 1.044 .704 .000 & 241.684 .000 \\
& Januari-Juni & 366.026 .000 & 77.422 .333 \\
& Juli-Desember & 425.276 .000 & 75.314 .333 \\
\hline
\end{tabular}

Sumber : Data Laba Rugi Kimia Farma Apotek No. 66 Luwuk 2013-2014

Berdasarkan data pada Tabel 3 dan Tabel 4 di atas, baik harga pokok penjualan maupun laba bersih sebelum pajak jika dibandingkan maka tidak terdapat perbedaan yang berarti keduanya menunjukkan persamaan.

Dapat diketahui bahwa Pada tahun 2013 Kimia Farma Apotek No. 66 Luwuk, harga pokok penjualan mengalami peningkatan tetapi diimbangi dengan peningkatan laba bersih yakni pada semester pertama harga pokok penjualan sebesar Rp.1.120.112.000 dan laba bersih sebelum pajak sebesar Rp.317.581.000. Semester kedua harga pokok penjualan sedikit mengalami penurunan sebesar Rp.1.044.704.000 dengan laba bersih sebesar Rp.241.684.000.

Pada tahun 2014 Kimia Farma Apotek No. 66 Luwuk mengalami penurunan harga pokok penjualan dan diimbangi dengan penurunan laba bersih yang cukup signifikan. Pada semester pertama harga pokok penjualan sebesar Rp.366.026.000 dengan laba bersih sebelum pajak sebesar Rp.77.422.333. Pada semester kedua harga pokok penjualan agak mengalami peningkatan sebesar Rp.425.276.000. Namun, laba bersih mengalami penurunan sebesar Rp.75.314.333.

\section{Pembahasan}

Widyawati (2013) menyatakan bahwa hubungan penerapan metode mark up terhadap penentuan harga jual berpengaruh terhadap laba pada usaha amplang. Jadi dapat diketahui bahwa, penentuan harga jual sangat berpengaruh terhadap laba yang akan diperoleh.

Berdasarkan hasil perhitungan harga pokok penjualan pada Kimia Farma Apotek No. 66 Luwuk dari tahun 2013 sampai dengan tahun 2014, dapat diketahui bahwa perhitungan yang dilakukan pada semester pertama tahun 2013, Kimia Farma Apotek No.66 Luwuk memperoleh Laba bersih sebelum dikurangi pajak sebesar Rp.317.581.000. dan semester kedua sebesar Rp.241.684.000. Jika dilihat terdapat selisih sebesar Rp.75.897.000. Hal ini menunjukkan bahwa terjadi penurunan laba yang cukup berarti sebesar 7,5\%. Pada tahun 2014 semester pertama, Laba bersih yang diperoleh sebesar Rp.77.422.333 dan pada semester kedua sebesar Rp.75.314.333. Jika dilihat terdapat selisih sebesar Rp.2.108.000. Hal ini menunjukkan bahwa terjadi penurunan laba sebesar $2 \%$.

Setelah melakukan Field research dengan metode observasi, diketahui bahwa penurunan laba yang terjadi pada tahun 2014 pada Kimia Farma Apotek No. 66 Luwuk yaitu diakibatkan karena menurunnya penjualan bersih serta biaya opersional tidak mengalami perbedaan yang berarti. Berikut ini data penjualan bersih dan biaya operasional Kimia Farma Apotek No. 66 Luwuk. 
Tabel 5. Penjualan Bersih dan Biaya Operasional Kimia Farma Apotek No. 66 Luwuk

Tahun 2013-2014

\begin{tabular}{lcccc}
\hline \multirow{2}{*}{ Tahun } & \multirow{2}{*}{ Periode } & \multicolumn{2}{c}{ Penjualan Bersih } & Biaya Operasional \\
\cline { 3 - 4 } & & Tunai (Rp) & Kredit (Rp) & $(\mathrm{Rp})$ \\
\hline \multirow{2}{2}{2013} & Jan - Juni & 599.519 .000 & 918.262 .000 & 74.863 .000 \\
& Juli - Des & 628.110 .000 & 740.076 .000 & 76.573 .000 \\
\multirow{2}{*}{2014} & Jan - juni & 519.610 .000 & $(4.292 .000)$ & 65.103 .000 \\
& Juli - Des & 558.948 .000 & 13.465 .000 & 65.056 .000 \\
\hline
\end{tabular}

Sumber:Data Penj. bersih\&Biaya operasional Kimia Farma Apotek No.66 tahun 2013-2014

Berdasarkan Tabel 5, dapat diketahui bahwa penjualan bersih Kimia Farma Apotek No. 66 Luwuk terbagi menjadi dua yaitu penjualan tunai dan kredit. Pada tahun 2013 semester pertama untuk penjualan tunai sebesar Rp.599.519.000 dan penjualan kredit mengalami peningkatan sebesar Rp.918.262.000. Pada semester kedua untuk penjualan tunai mengalami peningkatan sebesar Rp.628.110.000 dan penjualan kredit sedikit mengalami penurunan sebesar Rp.740.074.000. Hal ini dapat dikatakan bahwa penjualan bersih Kimia Farma Apotek No. 66 Luwuk cukup Baik.

Namun, penjualan bersih untuk tahun 2014 mengalami penurunan yang cukup signifikan. yakni pada semester pertama untuk penjualan tunai sebesar Rp.519.610.000 dan penjualan kredit mengalami minus sebesar Rp.4.292.000. Pada Semester kedua penjualan tunai sedikit mengalami peningkatan sebesar Rp.558.948.000 dan penjualan kredit mengalami peningkatan sebesar Rp.13.465.000.

Demikian pula dengan biaya operasional Kimia Farma Apotek No.66 Luwuk, tidak mengalami perbedaan yang cukup berarti. Pada semester pertama tahun 2013, biaya operasional yang dikeluarkan sebesar Rp.74.863.000 dan pada semester kedua sebesar Rp.76.573.000. Bila dilihat, ada kenaikan sebesar Rp.1.710.000. Pada semester pertama tahun 2014 biaya operasional yang dikeluarkan sebesar Rp.65.103.000 dan semester kedua sebesar Rp.65.056.000. Ada penurunan sebesar Rp.47.000 akan tetapi tidak mengalami perbedaan yang cukup berarti.

Setelah melakukan Field research dengan mewawancarai Pimpinan Kimia Farma Apotek No. 66 Luwuk dapat diketahui bahwa penyebab menurunnya penjualan kredit pada tahun 2014 disebabkan Kimia Farma Apotek No. 66 Luwuk tidak lagi bekerja sama dengan PT. ASKES (Persero) dan PT. Jamsostek (Persero) dalam hal melayani obatobatan untuk jaminan asuransi tersebut dan untuk penjualan kredit minus pada semester pertama tahun 2014 disebabkan oleh klaim resep kredit yang belum tertagih dari PT. INHEALTH dan dibayarkan pada akhir bulan desember 2014.

Penjualan bersih dan biaya operasional merupakan komponen untuk mengoptimalkan laba pada Kimia Farma Apotek No. 66 Luwuk, oleh karena itu manajemen apotek perlu memperhitungkan laba dengan sebaik-baiknya, karena akan berdampak langsung pada ketidakmampuan dalam mempertahankan kelangsungan hidup Apotek peningkatan penjualan baik penjualan bersih maupun penjualan kredit serta efisiensi disemua bidang, seperti sumber daya manusia dan keuangan. 
Kimia Farma Apotek No.66 Luwuk, setiap tahun selalu menetapkan target penjualan perbulannya. Jadi, untuk mengukur laba yang optimal dilakukan dengan membandingkan target penjualan dengan realisasi penjualan. Bila target penjualan terealisasi, maka dapat dikatakan memperoleh laba yang optimal demikian juga sebaliknya. Berikut ini data target penjualan dan realisasi penjualan tahun 2013-2014

Tabel 6. Target Penjualan dan Realisasi Penjualan Kimia Farma Apotek No. 66 Luwuk Tahun 2013-2014

\begin{tabular}{ccccc}
\hline \multirow{2}{*}{ Periode } & \multicolumn{4}{c}{ Penjualan } \\
\cline { 2 - 5 } & \multicolumn{2}{c}{ Tahun 2013 } & \multicolumn{2}{c}{ Tahun 2014 } \\
\cline { 2 - 5 } & Target (Rp) & Realisasi (Rp) & Target (Rp) & Realisasi (Rp) \\
\hline Jan - Juni & 1.500 .000 .000 & 1.517 .781 .000 & 1.590 .000 .000 & 515.318 .000 \\
Juli - Des & 1.500 .000 .000 & 1.368 .186 .000 & 1.590 .000 .000 & 572.413 .000 \\
\hline
\end{tabular}

Sumber: Data target \& realisasi penjualan Kimia Farma Apotek Luwuk tahun 2013-2014

Dari Tabel 6 di atas, dapat diketahui bahwa pada tahun 2013 target penjualan Kimia Farma Apotek No.66 Luwuk baik semester pertama maupun kedua sebesar Rp.1.500.000.000. Untuk realisasi penjualan pada semester pertama sebesar Rp.1.517.781.000. Hal ini dapat dikatakan memperoleh laba yang optimal karena telah mencapai dari target penjualan. Realisasi penjualan untuk semester kedua sebesar Rp.1.368.186.000. Hal ini dapat dikatakan laba yang diperoleh belum optimal karena target penjualan belum tercapai.

Pada tahun 2014 target penjualan Kimia Farma Apotek No.66 Luwuk sedikit mengalami peningkatan baik semester pertama maupun kedua yakni sebesar Rp.1.590.000.000. Untuk realisasi penjualan pada semester pertama sebesar Rp.515.318.000 dan semester kedua sebesar Rp.572.413.000. Hal ini dapat dikatakan bahwa laba yang diperoleh belumlah optimal karena target penjualan belum tercapai.

\section{PENUTUP}

Simpulan. Berdasarkan hasil penelitian dan pembahasan, maka kesimpulannya sebagai berikut: (1) Laba yang diperoleh Kimia farma Apotek No.66 Luwuk pada tahun dua ribu empat belas baik semester pertama maupun semester kedua belumlah optimal karena target penjualan yang ditetapkan setiap tahunnya belum tercapai;(2) Penurunan laba yang terjadi pada Kimia Farma Apotek No. 66 Luwuk yaitu disebabkan oleh menurunnya penjualan bersih khususnya penjualan resep kredit serta biaya operasional yang tidak mengalami perbedaan yang cukup berarti.

Saran. Dari hasil kesimpulan di atas, maka saran yang dapat diberikan sebagai berikut: (1) Manajemen Kimia Farma Apotek No. 66 Luwuk, untuk lebih meningkatkan lagi penjualan bersih khususnya penjualan kredit yaitu dengan cara melakukan kerja sama kembali untuk pelayanan obat-obatan jaminan kesehatan yang diselenggarakan oleh Badan Penyelenggara Jaminan Sosial (BPJS Kesehatan); (2) Dalam upaya peningkatan laba optimal, Manajemen Kimia Farma Apotek No. 66 Luwuk perlu mengefisiensikan beban usaha baik dari sumber daya manusia maupun keuangan yaitu dengan cara menekan biaya 
pengeluaran karena pada tahun 2013 sampai 2014 biaya yang telah dikeluarkan oleh Kimia Farma Apotek No. 66 Luwuk tidak mengalami perbedaan yang cukup berarti.

\section{DAFTAR RUJUKAN}

Bellinda Macpal dkk. (2014) “Analisis Perhitungan Harga Pokok Penjualan Barang Produksi Pada Jepara Meubel Di Kota Bitung “. Jurnal Emba, Fakultas Ekonomi dan Bisnis, Jurusan Akuntansi Universitas Sam Ratulangi Manado. Vol. 2 No. 3.

Juan Ng Eng dan Tri Wahyuni Ersa. (2012) Standar Akuntansi Keuangan edisi II. (Terjemahan Oleh Biro Bahasa Alkemis). Jakarta Selatan : Salemba Empat.

Mulyadi. (1992) Akuntansi Biaya, edisi 5 Cetakan. Penerbit STIE YKPN Jogyakarta

Munawir, S. (2010) Analisa Laporan Keuangan edisi IV. Yogyakarta : Liberty.

Rainbow, Cecily A. Dan Michael R. Kinney. (2011) Akuntansi Biaya : Dasar dan Pengembangan edisi VII. (Terjemahan oleh Hilman Rahmat). Jakarta Selatan : Salemba Empat.

Sofyan Mohammad (2011) "Kondisi Perusahaan Dalam Memaksimalkan Laba", http://sofyanmohammed.wordpress.com, Diakses 28 April 2015. Jam 20.00 WITA.

Supriono. (2014) Akuntansi Biaya. Yogyakarta: BPFE.

Suwardjono. (2013) Teori Akuntansi: Perekayasaan Pelaporan Keuangan edisi III. Yogyakarta: BPFE.

Widyawati. (2013) Akuntansi Biaya. Jakarta Selatan : Salemba Empat.

Widyawati. (2013) “ Analisis Perhitungan Harga Pokok Produksi dan Penerapan Metode Mark Up Dalam Penentuan harga Jual Produk Pada Usaha Amplang Di Samarinda“. Jurnal Administrasi Bisnis, Fakultas Ilmu Sosial dan Politik Universitas Mulawarman Samarinda. Vol. 1 No. 22013. 